\title{
Relationship of vegetation indices with herbicide phytotoxicity in winter cereals
}

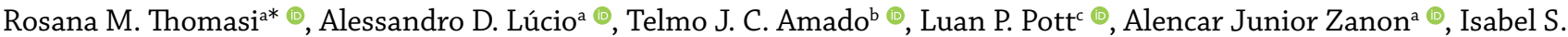 \\ Werle $^{\mathrm{d} \odot}$, Mariana Macedo ${ }^{\mathrm{e}}$, André R. Ulguim ${ }^{\mathrm{e}}$ (๑) \\ a Department of Crop Science, Federal University of Santa Maria, Santa Maria, RS, Brazil. b Soil Department, Federal University of Santa Maria, Santa \\ Maria, RS, Brazil; c Agricultural Engineering Department, Federal University of Santa Maria, Santa Maria, RS, Brazil. ${ }^{d}$ Crop, Soil and Environmental \\ Department, University of Arkansas, Fayetteville, United States of America. e Department of Crop Protection, Federal University of Santa Maria, \\ Santa Maria, RS, Brazil.
}

\begin{abstract}
Background: The evaluation of selective herbicides for weed control in winter cereals is extremely important. Simple methods to evaluate alterations caused by herbicides in the growth and development of winter cereals can be performed with vegetation indices.

Objective: Evaluate the potential of different vegetation indices by optical sensors to detect phytotoxicity caused by herbicides in winter cereals.

Methods: The experiment was conducted under field conditions, in a randomized block design with four replications. Herbicides were sprayed when the plants were at Z24. The phytotoxicity was evaluated at 7, 14 and 21 days after treatment (DAT) and the normalized difference vegetation index (NDVI) and the normalized difference red edge index (NDRE) at 16, 22 and 37 DAT.
\end{abstract}

Results: The herbicide 2,4-D was less phytotoxic to winter cereals, while metribuzin and saflufenacil caused higher percentages (up to 50\%) of visible injuries. The NDRE discriminated more precisely than NDVI the variations in winter cereals, showing alteration in the chlorophyll content due to the phytotoxicity caused by the herbicides. The canonical correlation analysis found an inverse relationship between phytotoxicity and vegetation indices.

Conclusions: The winter cereals studied were tolerant to herbicides, enabling the recovery of growth and development. The NDRE index was the most sensitive and showed greater potential in identifying injuries caused by herbicides. The canonical correlation analysis confirmed the inverse relationship between phytotoxicity and the reduction of vegetation indices.

Keywords: optical sensors; Avena sativa; Avena strigosa; Lolium multiflorum; Secale cereale

Journal Information:

ISSN - 2675-9462

Website: http://awsjournal.org

Journal of the Brazilian Weed

Science Society

How to cite: Thomasi RM, Lúcio $A D$, Amado TJC, Pott LP, Zanon AJ, Werle IS, Macedo M, Ulguim AR. Relationship of vegetation indices with herbicide phytotoxicity in winter cereals. Adv Weed Sci. 2021;39;e02100050. https://doi.org/10.51694/AdvWeedSci/2021;39:00017

Approved by:

Editor in Chief: Carlos Eduardo Schaedler

Associate Editor: Marcos Yanniccari

Conflict of Interest: The authors declare no conflict of interest regarding the publication of this manuscript.

Received: January 25, 2021

Approved: October 5, 2021

* Corresponding author: <rosanamthomasi@hotmail.com>

\section{(c) (7)}

This is an open-access article distributed under the terms of the

Creative Commons Attribution License, which permits unrestricted use, distribution, and reproduction in any medium, provided that the original author and source are credited.

Copyright: 2021

\section{Introduction}

The use of plants from the Poaceae family as soil cover presents a higher weed-suppressing capacity compared with other families, i.e. to those from the Fabaceae and Brassicaceae families (Bairabar et al., 2018). The use of cereals as cover crops is considered a relevant practice regarding weed management, aiding in the reduction of herbicide use (Didon et al., 2014), being an important option for herbicide resistance management practice (Pittman et al., 2019).

There are few studies that describe the phytotoxic effects of herbicides on winter cereals, suggesting that they must be used with caution (Dalazen et al., 2015), as they can affect plant growth and development, reducing their potential for soil coverage. At recommended doses of 2,4-D, metsulfuron-methyl and saflufenacil sprayed on cultivars of common oat (Avena sativa L.) and ryegrass (Lolium multiflorum Lam.), cultivated in a controlled environment, did not cause damage to the dry matter of the aerial part of plants, although phytotoxic effects of 2,4-D have been observed (Dalazen et al., 2015).

The use of acetolactate synthase (ALS) inhibitors herbicides in the management of winter cover crops is a common practice in the grain production areas in Brazil. It was observed that the cultivars of Avena sativa, URS Guria and URS Guará, demonstrated tolerance to iodosulfuron-methyl active ingredient, which was considered selective up to about six times the registered dose (Queiroz et al., 2017). Different doses of metsulfuron-methyl sprayed on Avena sativa at tillering stage provoked low phytotoxicity and did not interfere with grain yield (Cargnin et al., 2006).

The occurrence of phytotoxicity on cover crops can compromise the maintenance of soil cover. The proportion of photosynthetically active radiation entering the canopy varies according to the plant architecture of each crop. In this sense, rye (Secale cereale L.) prevents light penetration through the canopy by around 50\% (Hayden et al., 2014). Under these conditions, plants mainly absorb wavelengths in the red band $(660 \mathrm{~nm})$ and transmit extreme red $(730 \mathrm{~nm})$ to the lower portions of the canopy (Taylorson et al., 1969). Therefore, the extreme red wavelength is more abundant on the soil surface in situations of dense and healthy plant canopy (Ollinger, 2011). 
The maintenance of soil cover by using winter cereals promotes benefits in weed management due to the reduction of germination and competitive suppression of established individuals (Brust et al., 2014; Didon et al., 2014; Baraibar et al., 2018). The lack of stimulus for the germination and growth can be attributed to the different wavelengths of the electromagnetic spectrum that are absorbed, reflected or transmitted by the crop (Taylorson et al., 1969). Therefore, for the germination of the seeds of some weeds, it is necessary that light from the red band is absorbed in order to promote the activation of the phytochrome pigment, which is inactivated when the light is absorbed in the extreme red band (Yamashita et al., 2011). In addition to the impact on germination, the relation of red: extreme red wavelengths is fundamental for the regulation of other processes of plant growth and development, involving photomorphogenesis processes (Ballaré et al., 1995).

The technologies that use electromagnetic spectrum can be promising alternatives to evaluate the vegetative canopy of crops (Henry et al., 2004). The use of optical sensors is an option for the evaluation of phytotoxicity and growth, such as those that measure the normalized difference vegetation index (NDVI) or the normalized difference red edge index (NDRE). The NDVI is effective for assessing large areas and shows how dense and green the vegetation is, while the NDRE is more usual for determining chlorophyll content (Boiarskii et al., 2019). However, few studies associate the use of these indices with the phytotoxicity provided by herbicides in winter cereals.

The statistical techniques of multivariate analysis are excellent alternatives for identifying associations between different variables measured in agricultural experiments This identification allows for interpretations considering significant associations, thus increasing the scope of the inference to be made, a fact that is not possible when the effects are interpreted individually for each of the variables.

Among the various alternatives for multivariate tests, the canonical correlation analysis presentes as an efficient and interesting technique, because in addition to measureing the linear combinations between two groups of variables, it measures the maximum correlation between them (Hair et al., 2009). In this analysis, the main inferences are made from the first canonical pair, which establishes the maximum correlation between variable $\mathrm{X} 1$, belonging to group 1 , and variable $\mathrm{Y} 1$, belonging to group 2 (Cruz et al., 2012). However, the canonical statistics are interesting to verify the possible relations existing within a set of variables, inferring hypotheses about the possible causes for this association (Dieleman et al., 2000).

Thus, the evaluation of NDVI and NDRE sensors and their usage for recording damages of herbicides on winter cereals is necessary and it may be complementary to the visual identification of phytotoxicity. Therefore, the objective of this study was to evaluate the potential of vegetation indices by optical sensors to detect phytotoxicity caused by herbicides in winter cereals.

\section{Material and Methods}

A field experiment was conducted using a randomized block design with four replications, at the Federal University

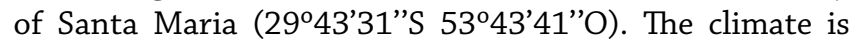
classified as humid subtropical CFA with a hot summer and no defined dry season (Heldwein et al., 2009); the soil is classified as sandy loam typic paleudalf (Santos et al., 2013).

The experimental units consisted of plots sized $5.0 \times 2.5$ meters $(\mathrm{m})$, totaling an area of $12.50 \mathrm{~m}^{2}$. The treatments were a factorial $5 \times 5$, whose factor A tested different winter cereals, sown according to the recommended sowing density (Table 1), while factor $\mathrm{D}$ consisted of the post-emergence application of the recommended doses of herbicides (Table 1).

The sowing took place was carried out on May $23^{\text {rd }}, 2018$, on the remains of a soybean crop and after the application of herbicide Paraquat ( $400 \mathrm{~g}$ a.i. ha ${ }^{-1}$ ). Basic fertilization was followed, using $230 \mathrm{~kg} \mathrm{ha}^{-1}$ of NPK 5-20-20 in furrow, and nitrogen fertilization as coverage. The coverage fertilization, was performed with the application of urea at a dosage of $100 \mathrm{~kg} \mathrm{ha}^{-1}$ at 30 days after emergence (DAE), when the plants achieved at Z21 stage, at the beginning of tillering (Zadoks et al., 1974).

The herbicides were sprayed at 57 DAE, on August $8^{\text {th }}$, 2018, when the crops were at Z24 (Zadoks et al., 1974). For the application, a backpack sprayer pressurized with $\mathrm{CO} 2$ was used, with the XR 110.015 nozzle spaced at $50 \mathrm{~cm}$, calibrated with an application pressure of $304.6 \mathrm{psi}$ and a spray volume of $150 \mathrm{~L} \mathrm{ha}^{-1}$. The herbicides phytotoxicity evaluations on the crops were performed using a percentage scale at 7,14 and 21 days after the application of the herbicide treatments (DAT). The rating range is from 0 to 100 , where 0 means no visible injury and 100 means the plant death.

To monitor the growth and development of the covers crops, evaluations were performed with the optical sensors GreenSeeker ${ }^{\circledast}$ and OptRx ${ }^{\circledast}$. The readings with the sensors

Table 1 - Winter cereals tested and their sowing densities

( $\mathrm{kg} \mathrm{ha}^{-1}$ ), with the herbicides and dosages used in the experiment. Santa Maria, 2018.

\begin{tabular}{|c|c|c|}
\hline Cereals & Cultivar & Densities (kg ha-1) \\
\hline Aveno sotivo & URS Guria & 90 \\
\hline Aveno strigoso & Ucraniana & 80 \\
\hline Lolium multiflorum & Comum & 25 \\
\hline Secale cereale & BRS Serrano & 40 \\
\hline Active ingredient & Dosage (g a. i. ha-1) & Commercial name \\
\hline Control & - & - \\
\hline 2.4-D & 670 & U $46 \mathrm{BR}^{\circledast}$ \\
\hline Saflufenacil ${ }^{1}$ & 35 & Heat $^{\circledR}$ \\
\hline Metsulfuron-methyl1 & 2.4 & Zartan $^{\circledR}$ \\
\hline Metribuzin & 336 & Sencor ${ }^{\circledast}$ \\
\hline
\end{tabular}

${ }^{1} 0.5 \%$ of Dash ${ }^{\circledR}$ mineral oil was added as recommended. 
were performed at 16, 22 and 37 DAT. The evaluations were performed with linear walking in the plots. The sensor was placed at $0.60 \mathrm{~m}$ above the vegetative canopy. The GreenSeeker $^{\circledR}$ sensor measures canopy reflectance in the near infrared (NIR) and red regions. Thus, it calculates the normalized difference vegetation index (NDVI), where values closest to 1 indicate high ground cover and values closest to 0 indicate low cover or bare soil, according to the equation:

$$
N D V I=\frac{N I R-R E D}{N I R+R E D}
$$

The OptRx ${ }^{\circledR}$ sensor, in addition to the NDVI index, measures the normalized difference red-edge index (NDRE), that is, it measures the reflectance in the range of extreme red (REDEDGE) and near infrared (NIR), according to the equation:

$$
N D R E=\frac{N I R-R E D E D G E}{N I R+R E D E D G E}
$$

The variables of phytotoxicity, NDVI and NDRE on each evaluation date were subjected to analysis of variance $(p \leq 0.05)$ using software R (R Development Core Team, 2019). When significance was verified, the means were compared using the Scott Knott test ( $\mathrm{p} \leq 0.05)$, and the results were presented using boxplot graphics (R Development Core Team, 2019). The canonical correlation analysis was performed to identify the association between groups of variables. Thelinear combination of phytotoxicity and NDRE and variables of phytotoxicity and NDVI form three groups of canonical variables, as follows, group 1 contains the variables: phytotoxicity at 7 DAT, 14 DAT, 21 DAT, group 2: NDRE at 16 DAT, 22 DAT, 37 DAT and group 3: NDVI at 16 DAT, 22 DAT, 37 DAT.

For the diagnosis of multicollinearity, the condition number (NC) and the variance inflation factor (VIF) was used. On the other hand, when it was verified low multicollinearity of the groups (NC < 100 and VIF <10), two analyzes of canonical correlation between groups 1 and 2 and groups 1 and 3 were performed. The interpretation of the canonical correlation analysis was based on canonical cross-loadings, as they are more efficient and less influenced by multicollinearity, because even if these are of low magnitude, they can still generate less reliable interpretations (Diel et al., 2020).

\section{Results and Discussion}

There were interactions between the factors tested in all phytotoxicity evaluations and at 16 DAT and 22 DAT for NDRE and 22 DAT and 37 DAT for NDVI. These responses show a change in the evaluated rates in the combination of winter cereals types and herbicides. At 37 DAT, the main NDRE effects of winter cereals were unfolded, while at 16 DAT, the main NDVI effects of each factor were unfolded.

The herbicide 2,4-D did not provoke phytotoxicity regardless of the time of evaluation, and did not differ from the control treatment (without herbicide application) (Figures 1 to 3). Similar responses were reported for these crops when 2,4-D was sprayed at a recommended dose

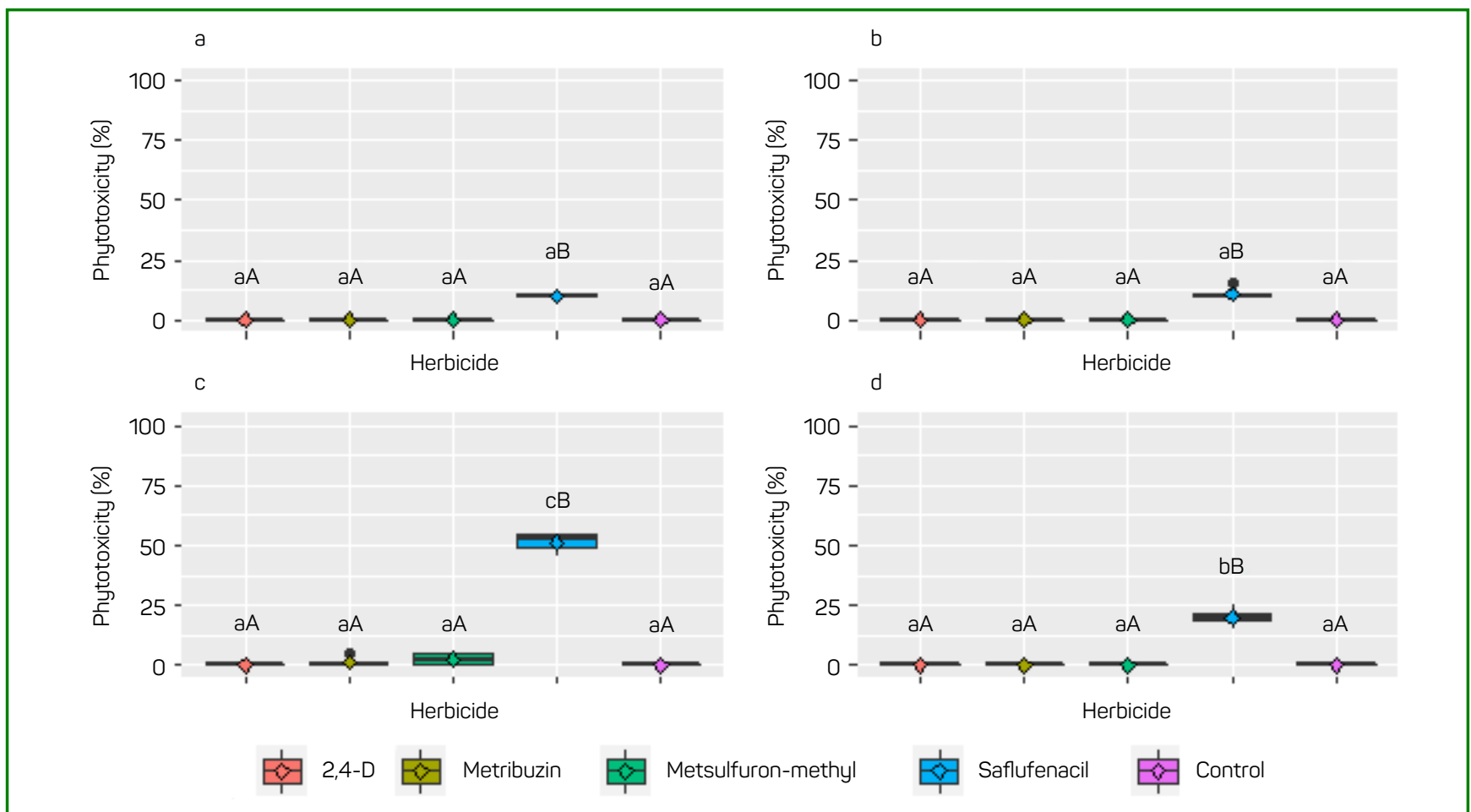

Figure 1 - Phytotoxicity (\%) of herbicides in winter cereals Aveno sativo (a), Avena strigoso (b), Lolium multiflorum (c) and Secale cereale (d), evaluated at 7 days after application of treatments. Santa Maria, 2018. * Means do not followed by the same lower case letter comparing crops for each herbicide, and by the same upper case letter comparing herbicides for each winter cereal, differ by the Scott Knott test ( $p \leq 0.05)$. 


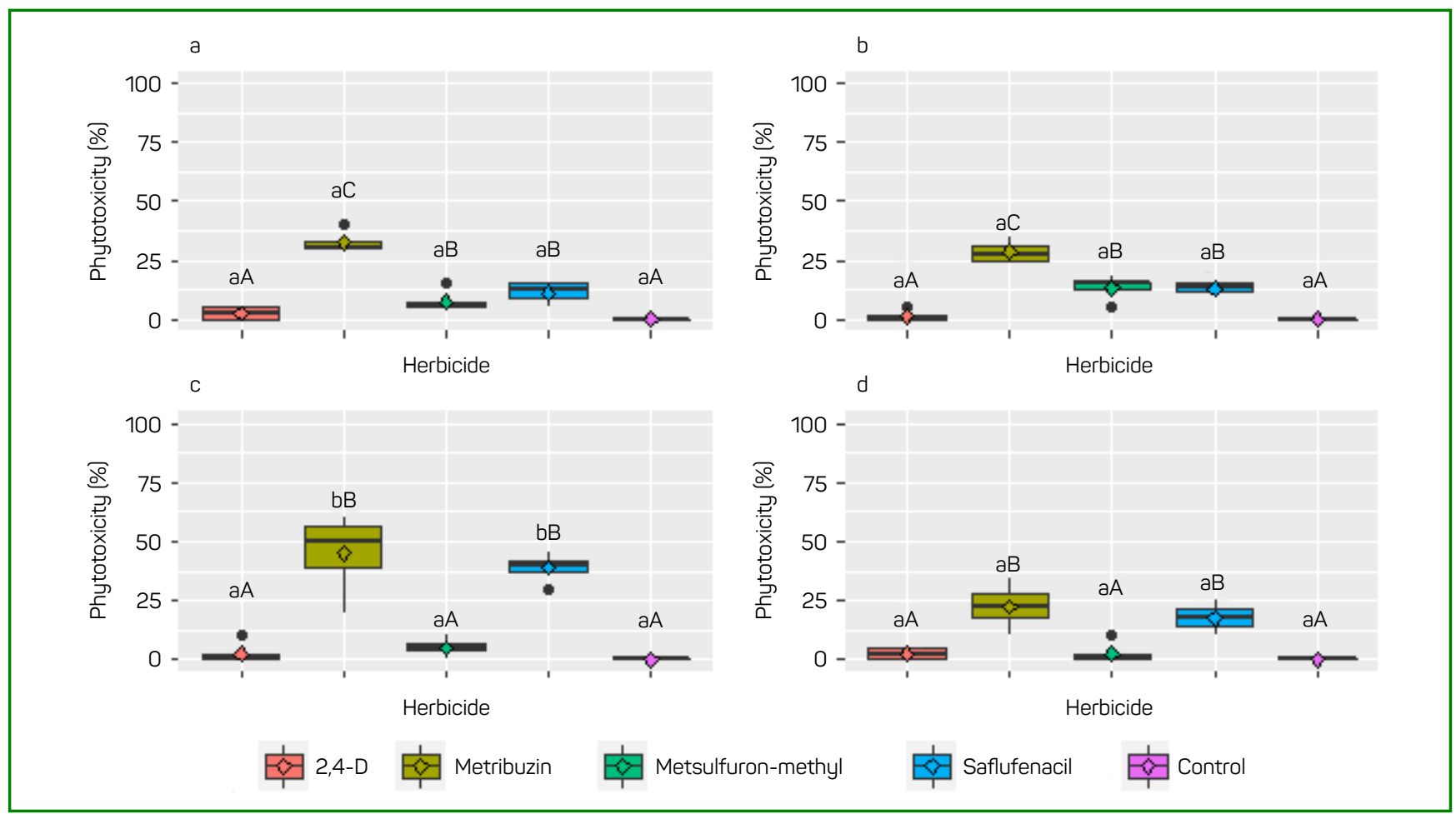

Figure 2 - Phytotoxicity (\%) of herbicides in winter cereals Aveno sativo (a), Aveno strigoso (b), Lolium multiflorum (c) and Secale cereole (d), evaluated at 14 days after application of treatments. Santa Maria, 2018. * Means do not followed by the same lower case letter comparing crops for each herbicide, and by the same upper case letter comparing herbicides for each winter cereal, differ by the Scott Knott test ( $p \leq 0.05)$.

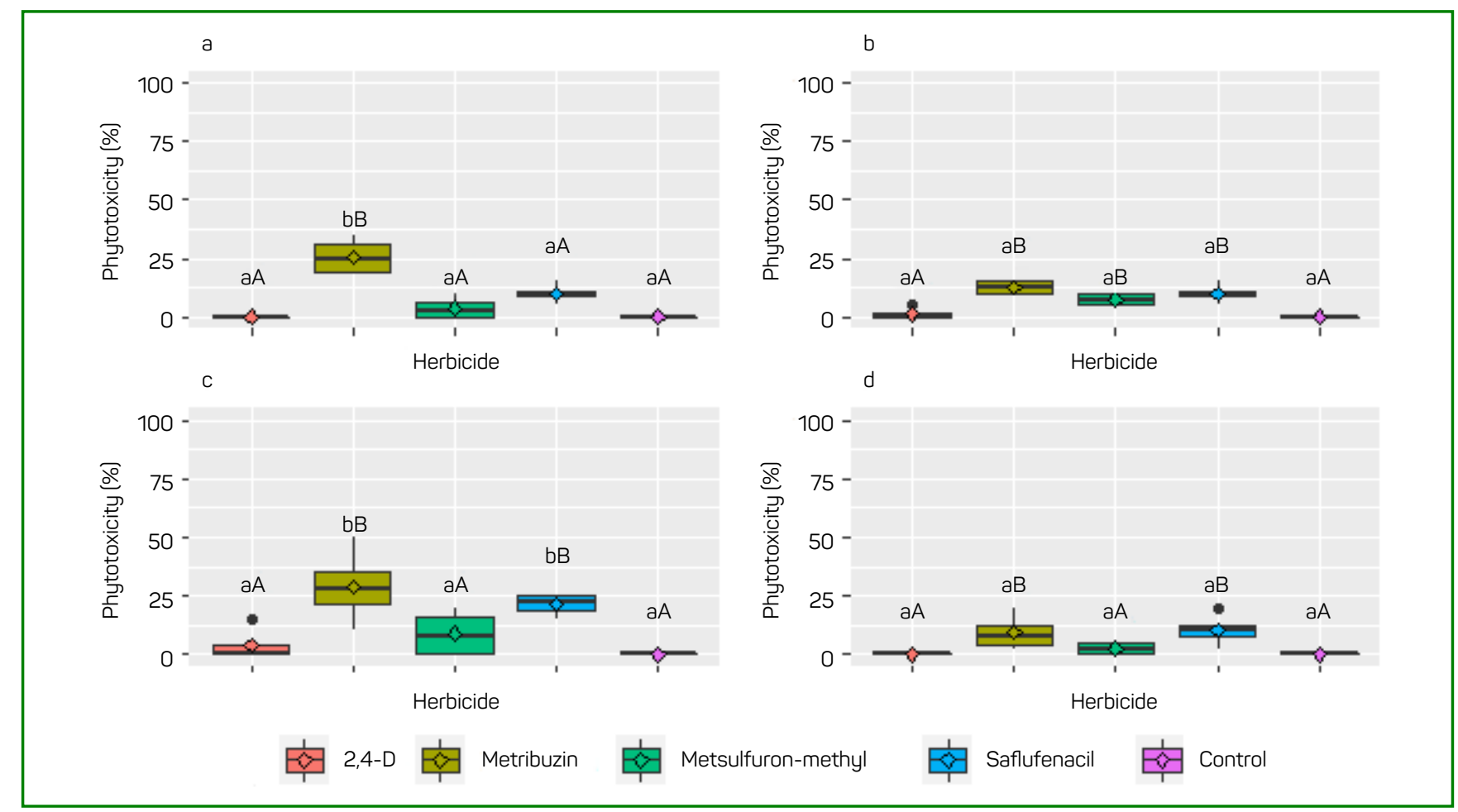

Figure 3 - Phytotoxicity (\%) of herbicides in winter cereals Aveno sotivo (a), Aveno strigoso (b), Lolium multiflorum (c) and Secole cereole (d), evaluated at 21 days after application of treatments. Santa Maria, 2018. * Means do not followed by the same lower case letter comparing crops for each herbicide, and by the same upper case letter comparing herbicides for each winter cereal, differ by the Scott Knott test ( $p \leq 0.05)$. 
(Vargas et al., 2005; Dalazen et al., 2015). In addition, the architecture of poaceous species imposes some difficulties, resulting in low absorption and translocation of 2,4-D, due to morphological and metabolic characteristics, due the synthetic auxin is slightly conjugated, minimizing the phytotoxic effects (Sterling et al., 1997), promoting a high selectivity of the herbicide to the tested crops.

Similarly, the herbicide metsulfuron-methyl promoted small or no injury to the winter cereals tested, with visual injury at 14 DAT in the genus Avena (7.50\% for Avena sativa and $13.25 \%$ for Avena strigosa) (Figure $2 \mathrm{a}$ and $2 \mathrm{~b}$ ), which persisted until 21 DAT in Avena strigose (7.5\%) (Figure 3b). In the wheat, damages caused by metsulfuron-methyl were observed at 7 DAT with subsequent recovery of the plants after 21 DAT (Agostinetto et al., 2016). The application of this herbicide on Avena strigosa did not cause visual damage to the plants, promoting a reduction in the dry mass of the crop (Dalazen et al., 2015), corroborating the selectivity of this herbicide observed in this study.

The herbicide metribuzin showed phytotoxicity symptoms for the species tested from 14 DAT, with highlight the greater damage to the genus Avena in relation to the other herbicides (32.50\% for Avena sativa and $28.75 \%$ for Avena strigosa) (Figures 2a and $2 \mathrm{~b}$ ). These symptoms were still evident until 21 DAT, but in a lower percentage, showing the recovery of the plants (Figure 3 ).

A similar result was observed in different sugarcane cultivars, in which at 21 DAT the plants showed less symptoms of metribuzin (Monquero et al., 2011). However, different Avena sativa cultivars showed injuries after the application of this herbicide, resulting in lower yield compared to metsulfuron-methyl and bentazon herbicides (Cargnin et al., 2006). In our study, it also was noted, that it was observed a phytotoxicity of $45 \%$ for the application of metribuzin on Lolium multiflorum, differing from control (without application), but without difference to the herbicide saflufenacil at 14 and 21 DAT (Figure $2 c$ and 3c).

For Lolium multiflorum and Secale cereale, the herbicide saflufenacil caused greater phytotoxicity at 7 DAT (around $50 \%$ and $20 \%$, respectively), compared to the control treatment without application, also differing from the other tested species (Figures $1 \mathrm{c}$ and $1 \mathrm{~d}$ ). The appearance of these symptoms is due to its characteristics, little herbicide translocation, rapidly inducing leaf necrosis in the presence of light (Grossmann et al., 2010). The phytotoxicity symptoms of saflufenacil in Lolium multiflorum continued to be accentuated at 14 and 21 DAT $(38.75 \%$ and $21.75 \%$, respectively), suggesting the lower tolerance of this species to this herbicide (Figures $2 c$ and $3 c$ ).

It is noteworthy that although symptoms of phytotoxicity were observed, their damages were small, allowing the recovery of the plants, however, the selectivity of herbicides must also be evaluated based on other variables. The association of this inference with the evaluation with optical sensors is important to confirm this observation. In this sense, at 16 DAT, there was a reduction in the NDRE of Secale cereale provided by the herbicides 2,4-D and metribuzin (Figure 4d), and by the latter in Lolium multiflorum (Figure 4c).

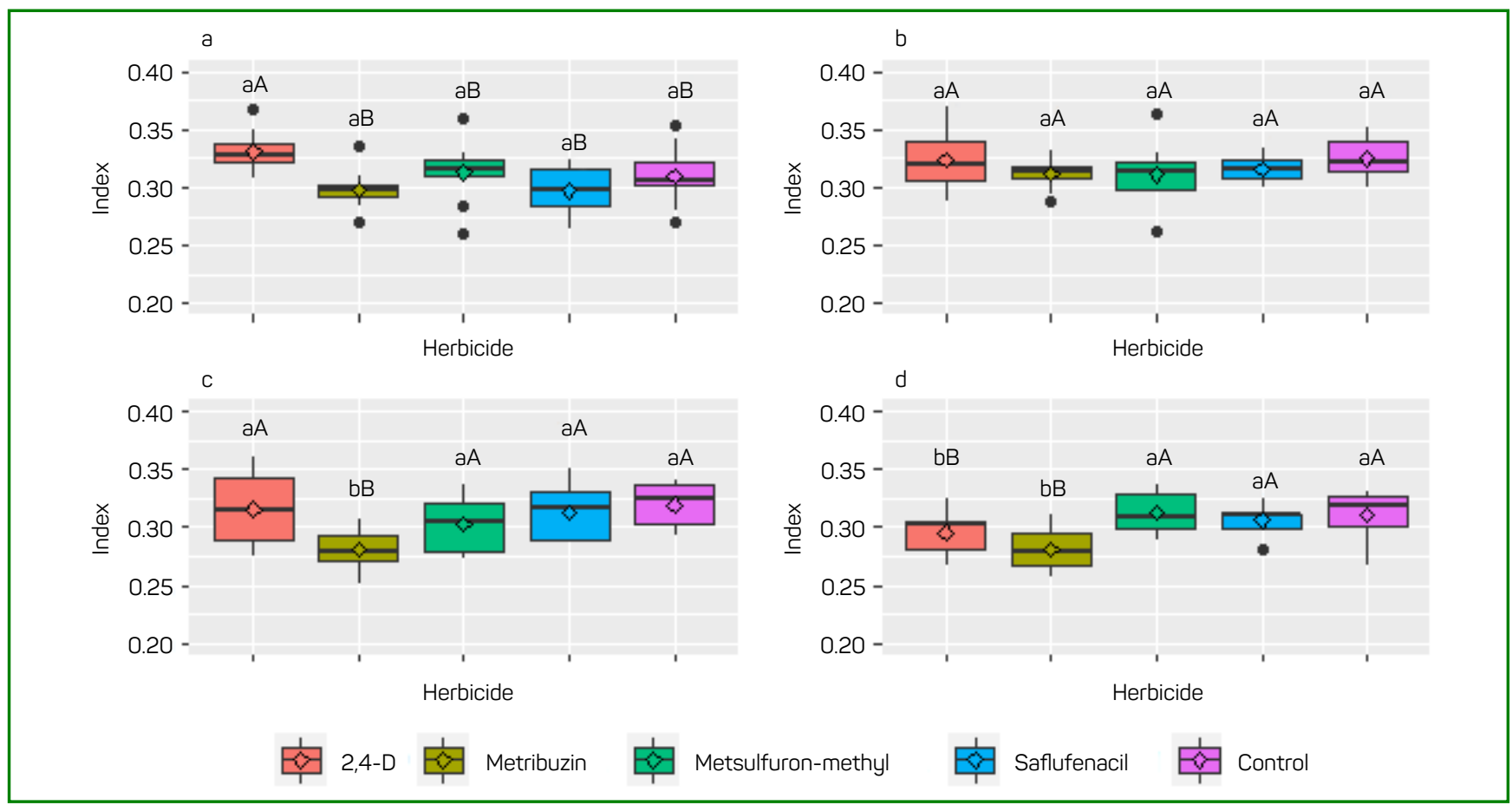

Figure 4 - Normalized difference red edge index (NDRE) in different winter cereals evaluated at 16 days after treatment of different herbicides. Santa Maria, 2018. a) Avena sotiva, b) Avena strigoso, c) Lolium multiflorum and d) Secale cereale. * Means do not followed by the same lower case letter comparing cultures for each herbicide, and by the same capital letter comparing herbicides for each winter cereal, differ by the Scott Knott test ( $p \leq 0.05)$. 
This reduction caused by the herbicide metribuzin agrees with the highest phytotoxicity at 14 DAT for the species (Figure $2 c$ and d), but no visual injury by 2,4-D was observed. This result corroborates what was observed in wheat by the application of 2,4-D, where no phytotoxicity was observed, but there was a reduction in the content of chlorophylls and carotenoids (Agostinetto et al., 2016). Thus, there is an indication of the efficiency of using the optical sensor to capture changes in chlorophyll content under conditions of imperceptible visual injury.

At 22 DAT, the herbicides that provided the greatest reductions in NDRE on Avena sativa and Lolium multiflorum were metribuzin and metsulfuron-methyl (Figure 5c). The reduction by metribuzin herbicide corroborates the results of phytotoxicity at 21 DAT, but it was not possible to detect damage to winter cereals on a visual scale by metsulfuron-methyl, as it was observed for 2,4-D at 16 DAT. In general, there was a reduction in the NDRE provided by the herbicide metribuzin in all cereals in relation to the other herbicides and control treatment. Photosystem II inhibiting herbicides, such as metribuzin, show competitive binding kinetics with plastoquinone $\mathrm{QB}$ and compete for this binding site in the $\mathrm{D} 1$ protein, interrupting the electron flow, with lipid peroxidation in the chloroplast membrane (Hess, 2000). Therefore, this reduction in NDRE by metribuzin may be related to chlorophyll degradation.
The differences in NDRE found between winter cereals when submitted to the application of 2,4-D and metsulfuron-methyl do not corroborate the phytotoxicity results (Figures 1, 2 and 3). Based on this result, it can be inferred that the reduction in chlorophyll content, measured indirectly by the sensor, was not perceptible on a visual scale. Thus, the use of the sensor to assess plant injuries after herbicide application is a promising tool. At 37 DAT, there was no interaction between winter cereals and herbicides, which can be attributed to plant recovery after phytotoxicity symptoms. Among the winter cereals, Secale cereale differed from the others, presenting a lower NDRE (Figure 6).

For the NDVI vegetation index at 16 DAT, the simple effects of each factor were unfolded, where the winter cereals Avena sativa and Secale cereale showed low NDVI, which can be attributed to the lower tillering of these crops in relation to Avena strigosa and Lolium multiflorum (Figure 7a). Among the herbicides studied, metribuzin and saflufenacil provided the greatest reduction in vegetation indices (Figure 7b). For the evaluation at 22 DAT, in Lolium multiflorum the phytotoxicity evidenced by metribuzin and saflufenacil at 21 DAT (Figure 2) was verified by the reduction of NDVI (Figure 8c).

The evaluation of NDVI at 37 DAT showed different reflectance values as previously observed. In Avena sativa there were reductions in the NDVI for all herbicides in

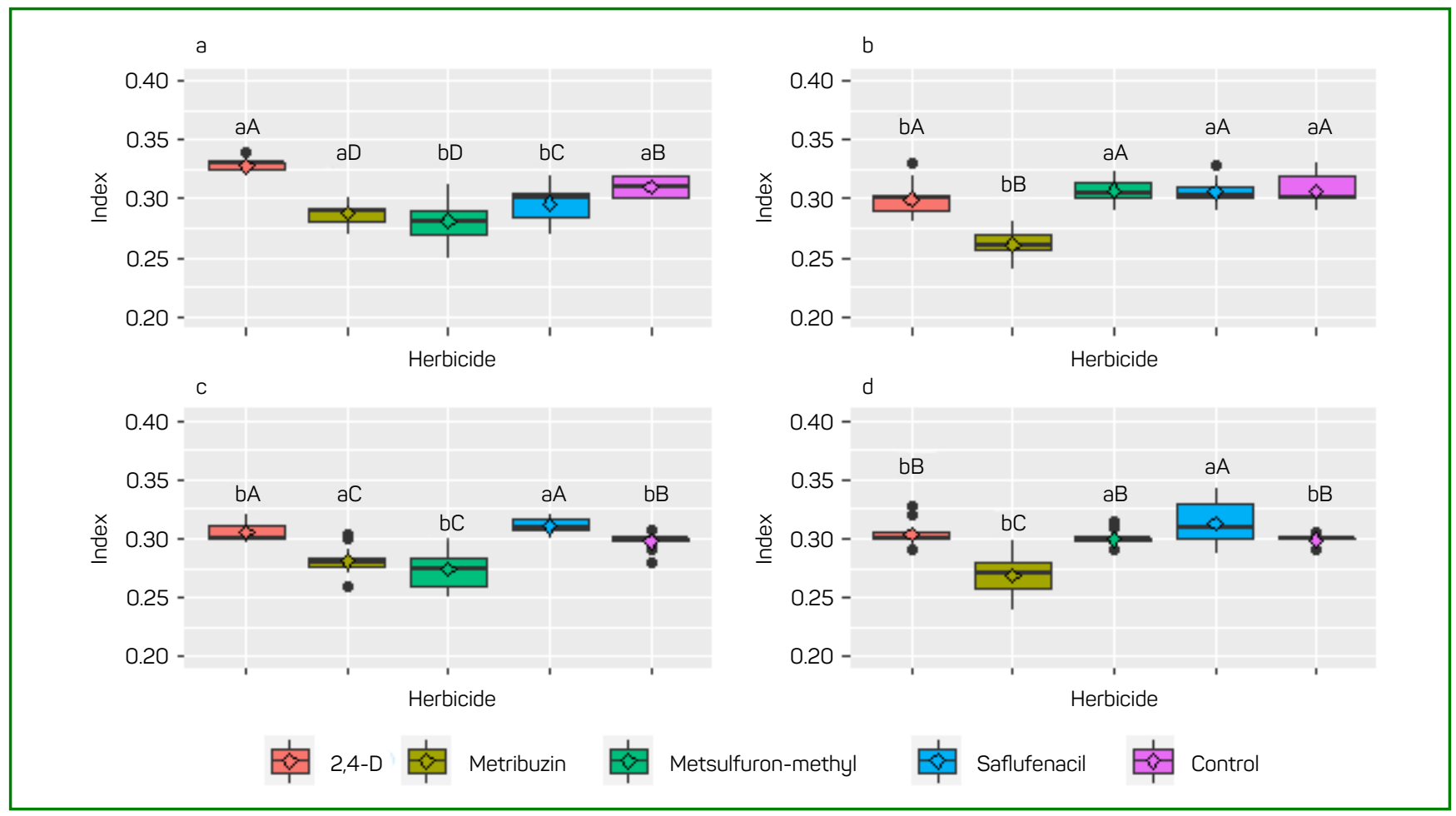

Figure 5 - Normalized difference red edge index (NDRE) in different winter cereals evaluated at 22 days after treatment of different herbicides. Santa Maria, 2018. a) Aveno sativo, b) Aveno strigoso, c) Lolium multiflorum and d) Secale cereale. * Means do not followed by the same lower case letter comparing cultures for each herbicide, and by the same capital letter comparing herbicides for each winter cereal, differ by the Scott Knott test ( $p \leq 0.05)$. 
comparison to control treatment (Figure 9a), while Secale cereale continued without variations, equaling the control (Figure 9d). Although the interaction at 37 DAT was significant. In general, there were few variations in the NDVI, therefore, it can be inferred that the NDVI index was not efficient to estimate the damages caused by herbicides to the tested species.

The readings produced by the Green Seeker ${ }^{\circledR}$ sensor, indicated by the NDVI index, saturate more easily, making it difficult to detect small changes, especially in very dense canopies (Freeman et al., 2003). Therefore, small changes become insignificant, which may explain the changes observed for the sensor in the present study, especially at 37 DAT. On the other hand, the leaves are more translucent to extreme red, so, there is greater penetration of this band into the canopy, making the NDRE capable of demonstrating more satisfactorily the condition of the vegetation, especially in canopies with many layers of leaves (Boiarskii et al., 2019). Therefore, the NDRE showed lower variations in the development of the tested winter cereals by the application of different herbicides. However, this inference can be confirmed through canonical correlation analysis.

When the diagnosis of multicollinearity for the canonical correlation analysis are performed, it was found NC for group 1 of 16.09, for group 2 of 2.90 and for group 3 of 2.42 , indicating low multicollinearity, as NC $<100$. The VIF for the variables of group 1, phytotoxicity at 7, 14 and 21 DAT were 1.23, 4.19 and 3.92, respectively. For the variables of group 2, NDRE at 16, 22 and 37 DAT, they were of 1.95, 1.76 and 1.18 , respectively, and for the variables of group 3 , NDVI at 16, 22 and 37 DAT, they were of 1.21, 1.21 and 1.00, respectively. These results of the multicollinearity diagnosis are important, because according to Diel et al. (2020), they indicate that the canonical correlation analysis is reliable and efficiently evidence the influence of one group over another.

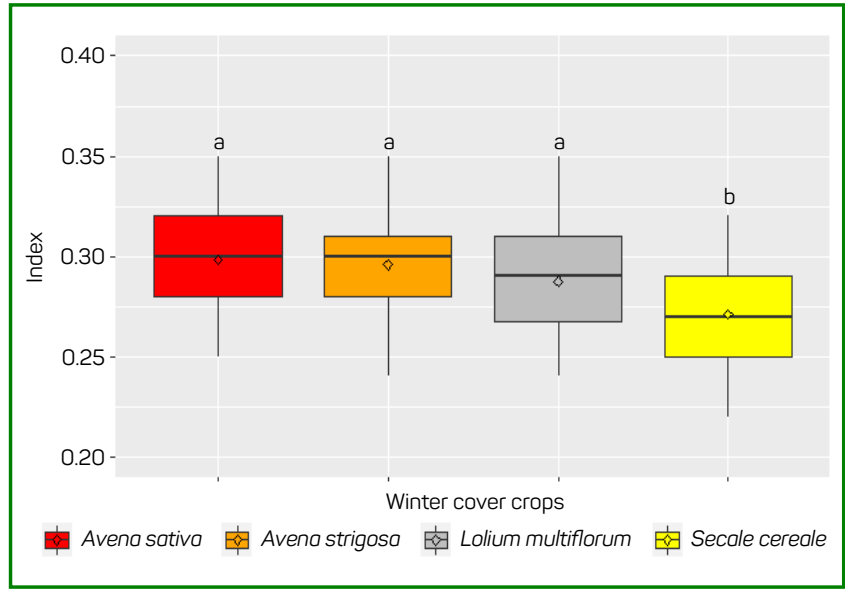

Figure 6 - Normalized difference red edge index (NDRE) in different winter cereals evaluated at 37 days after treatment. Santa Maria, 2018. *Means do not followed by the same lower case letter compare between winter cereals, differ by the Scott Knott test ( $\mathrm{p} \leq 0.05)$.

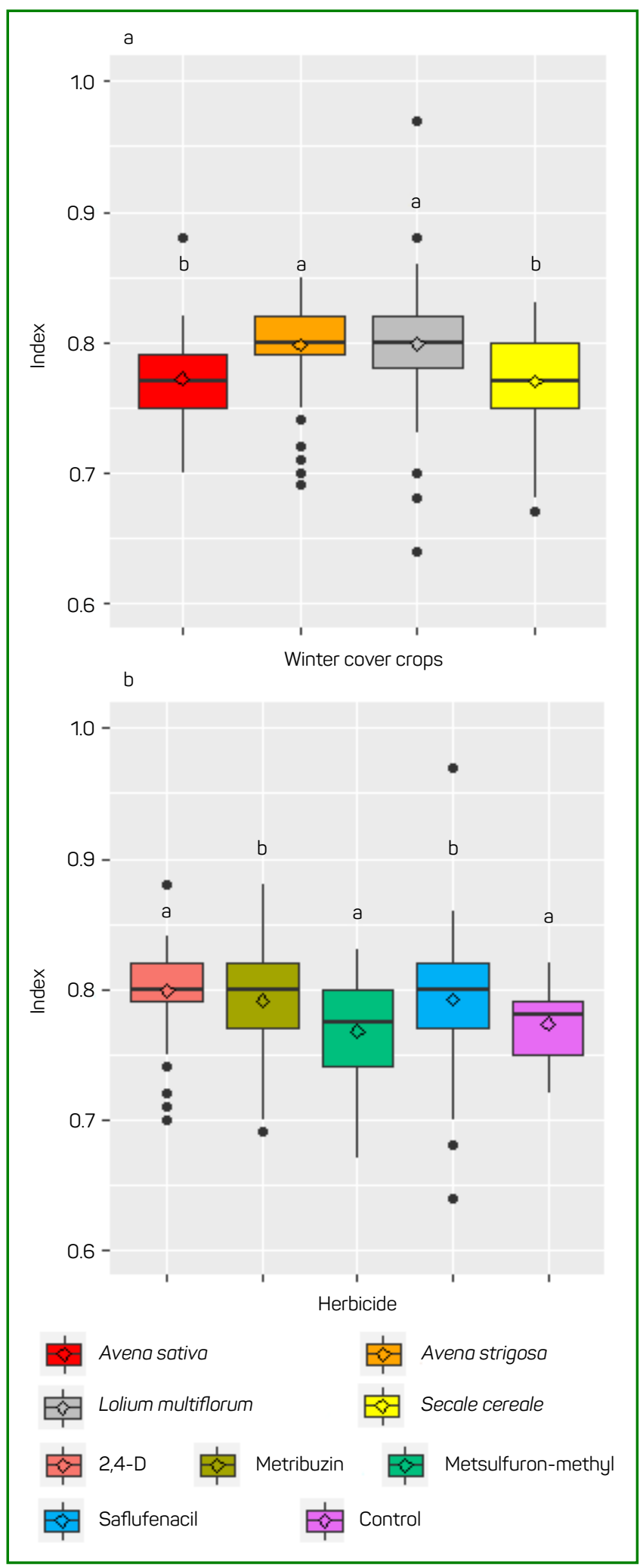

Figure 7 - Normalized difference vegetation index (NDVI) in different winter cereals evaluated at 16 days after treatment of different herbicides. Santa Maria, 2018. a) NDVI between different winter cereals and b) NDVI between different herbicides. *Means do not followed by the same lower case letter compare between winter cereals or herbicides, differ by the Scott Knott test. 


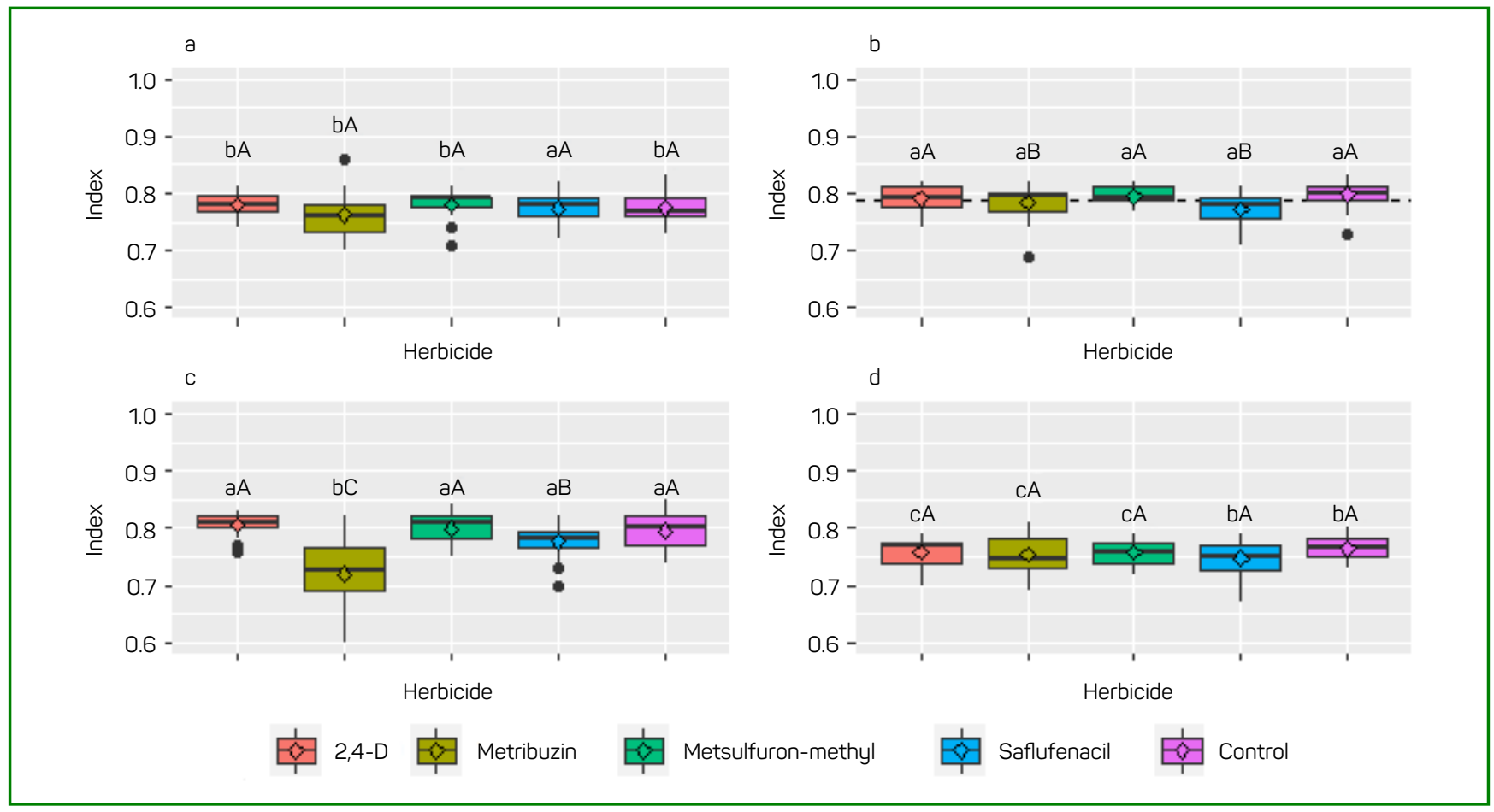

Figure 8 - Normalized difference vegetation index (NDVI) in different winter cereals evaluated at 22 days after treatment of different herbicides. Santa Maria, 2018. a) Aveno sativo, b) Aveno strigoso, c) Lolium multiflorum and d) Secale cereale. * Means do not followed by the same lower case letter comparing crops for each herbicide, and the same upper case letter comparing herbicides for each winter cereal, differ by the Scott Knott test ( $p \leq 0.05)$.

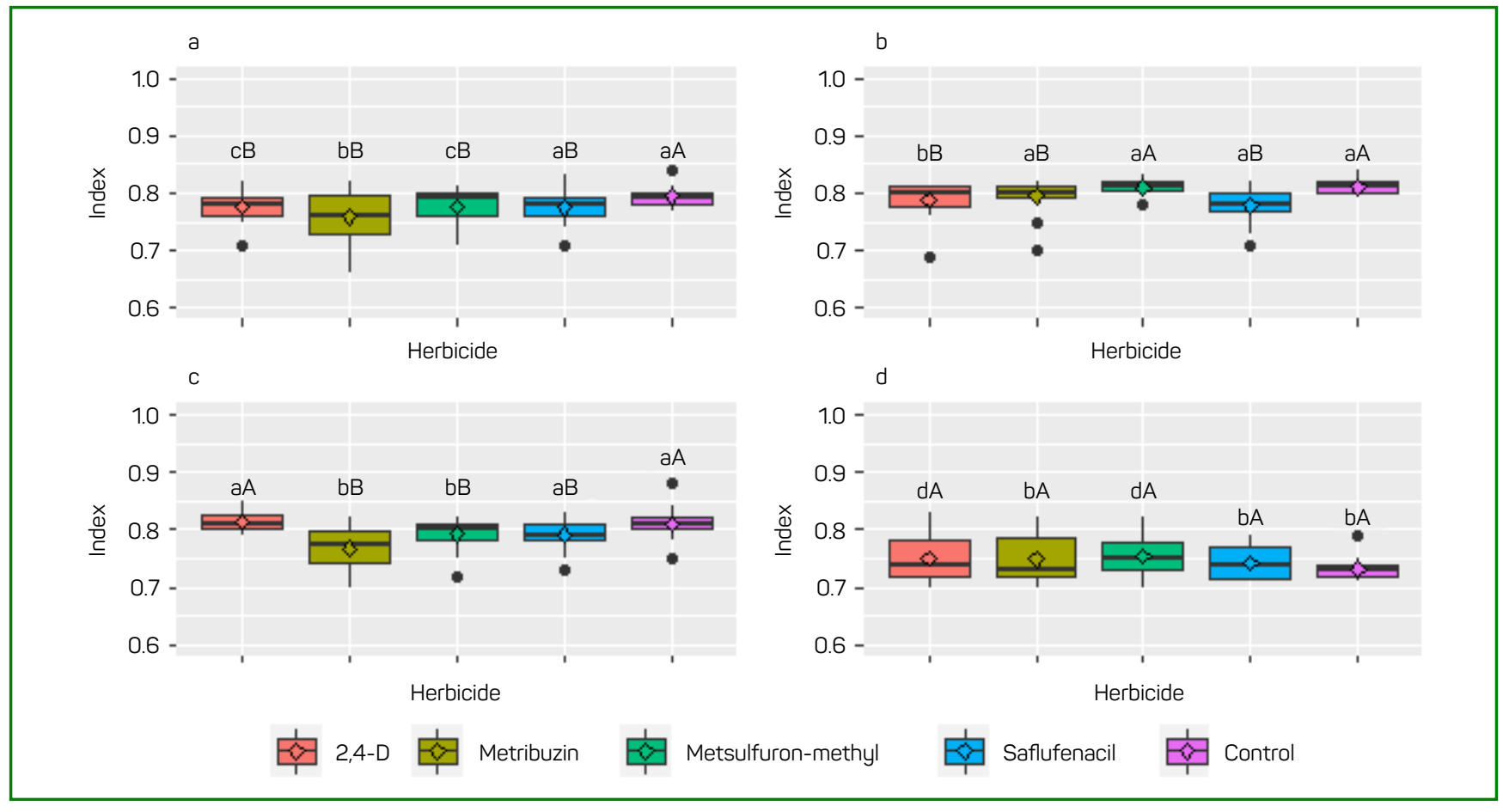

Figure 9 - Normalized difference vegetation index (NDVI) in different winter cereals evaluated at 37 days after treatment (DAT) of different herbicides. Santa Maria, 2018. a) Avena sotiva, b) Avena strigosa, c) Lolium multiflorum and d) Secale cereale. * Means do not followed by the same lower case letter comparing crops for each herbicide, and the same upper case letter comparing herbicides for each winter cereal, differ by the Scott Knott test ( $\leq \leq 0.05)$. 
The first canonical pair of the canonical correlation between group 1 and group 2 showed a moderate and significant correlation magnitude (0.56). Thus, the inferences between the groups will occur from it. Canonical cross-loadings of opposite signs and average magnitude are observed between the phytotoxicity variables at $14(0.367)$ and 21 DAT (0.302) and the NDRE at $16(-0.352)$ and 22 DAT (-0.532) (Table 2 ). Thus, the greater the phytotoxicity caused by herbicides in winter cereals, lower NDRE, showing that there is an interdependent relationship between canonical groups. Phytotoxicity symptoms became more noticeable starting at 14 DAT, being evidenced by the NDRE starting at 16 DAT. Therefore, canonical cross-loadings found that phytotoxicity causes alterations in the NDRE, as a consequence, as the percentage of phytotoxicity increases, the NDRE is decreased.

The canonical correlation between group 1 and group 3 showed similar results (Table 2). Only the first canonical pair was significant and had a moderate magnitude correlation of 0.62 . Thus, as in the analysis of canonical correlation between

Table 2. Canonical cross-loads for two groups of phytotoxicity variables and normalized difference red edge index (NDRE) variables and for two groups of phytotoxicity variables and normalized difference vegetation index (NDVI) variables. Santa Maria, 2018.

Variables

Canonical cross-loads $2^{\text {ns }}$ $3^{\text {ns }}$

NDRE

\begin{tabular}{|l|c|c|c|}
\hline PHYTOTOXICITY 7 DAT & -0.216 & 0.161 & 0.000 \\
\hline PHYTOTOXICITY 14 DAT & 0.367 & 0.132 & 0.000 \\
\hline PHYTOTOXICITY 21 DAT & 0.302 & 0.118 & 0.000 \\
\hline & & $G 2$ & \\
\hline NDRE 16 DAT & -0.352 & -0.133 & 0.000 \\
\hline NDRE 22 DAT & -0.532 & 0.034 & 0.001 \\
\hline NDRE 37 DAT & 0.001 & -0.094 & 0.005 \\
\hline Canonical correlations r & 0.56 & 0.17 & 0.00 \\
\hline P-valor & 0.00 & 0.67 & 0.96 \\
\hline NDVI & & & \\
\hline & & $G 1$ & \\
\hline PHYTOTOXICITY 7 DAT & 0.023 & -0.243 & -0.030 \\
\hline PHYTOTOXICITY 14 DAT & 0.570 & -0.098 & 0.005 \\
\hline PHYTOTOXICITY 21 DAT & 0.506 & -0.080 & -0.091 \\
\hline & & $G 2$ & \\
\hline NDVI 16 DAT & -0.311 & 0.096 & -0.145 \\
\hline NDVI 22 DAT & -0.616 & 0.012 & 0.023 \\
\hline NDVI 37 DAT & 0.045 & 0.217 & 0.083 \\
\hline Canonical correlations r & 0.62 & 0.24 & 0.19 \\
\hline P-Valor & $1.21 E-03$ & 0.12 & 0.10 \\
\hline
\end{tabular}

phytotoxicity and NDRE, it was also possible to identify interrelation between phytotoxicity and NDVI from the canonical cross-loadings of phytotoxicity at 14 DAT (0.570) and the NDVI at 22 DAT $(-0.616)$. This inverse relationship shows that the reduction of NDVI at 22 DAT is correlated with the highest percentages of phytotoxicity at 21 DAT. At 16 DAT, the interaction between the factors was not significant and, at 37 DAT, there were small variations between the NDVI, evidenced by the low magnitude of the canonical crossloadings of these variables (-0.311 and 0.045 , respectively).

The phytotoxicity caused by herbicides on winter cereals is associated with the variation in vegetation indices, both NDRE and NDVI. Canonical correlation analysis was used to predict associations between soil properties and weed abundance, showing that the use of atrazine in corn (Zea mays L.) changes the $\mathrm{pH}$ and the percentage of organic carbon, which defines the species that will be present in the site (Dieleman et al., 2000).

Part of the herbicide absorbed by tolerant plants is slightly metabolized and transformed into non-phytotoxic molecules, but part of this herbicide still reaches the site of action, and as a consequence the phytotoxicity symptoms will appear, such as structural damage (visual symptoms) or physiological damage (reduction in growth rate) (Carvalho et al., 2009). Because of this, even being tolerant, winter cereals showed symptoms of phytotoxicity caused by the used herbicides. The accumulation of protoporphyrin IX and hydrogen peroxide was lower in corn (Zea mays L.) than in American black nightshade (Solanum americanum Mill.), after the application of saflufenacil (Grossmann et al., 2010), however, even in smaller quantities, the accumulation still occurs, which can provide phytotoxicity symptoms with the later recovery of the plants, as it can be seen in this study.

In general, it can be inferred that the 2,4-D herbicide had greater selectivity for the winter cereals tested in all evaluations, while saflufenacil and metribuzin promoted greater phytotoxicity for the crops. Among the species tested, Secale cereale showed the highest tolerance to herbicides, while Lolium multiflorum was the least tolerant, based on the phytotoxicity evaluation. However, other evaluations are necessary to identify the damage to plants, where evaluations with the use of optical sensors can be an alternative. The use of optical sensors to verify herbicide phytotoxicity in winter cereals is efficient, as they can evidence injuries that are not noticeable on a visual scale for the reduction in the vegetation index. The normalized difference red-edge index (NDRE) was more accurate in detecting small alterations in chlorophyll content than the normalized difference vegetation index (NDVI). The canonical correlation analysis confirmed the inverse relationship between phytotoxicity and the variation of the NDRE and NDVI indices.

\section{Author's contributions}

All authors contributed with equity in the steps to carry out this study. 


\section{References}

Agostinetto D, Perboni LT, langaro AC, Gomes J, Fraga DS, Franco $\mathrm{JJ}$. Changes in photosynthesis and oxidative stress in wheat plants submmited to herbicides application. Planta Daninha. 2016;34(1):1-9. Available from: https://doi.org/10.1590/S0100-83582016340100001

Ballaré CL, Scopel AL, Sánchez RA. Plant photomorphogenesis in canopies, crop growth, and yield. HortScience. 1995;30(6):1172-81. Available from: https://doi.org/10.21273/HORTSCI.30.6.1172

Baraibar B, Hunter MC, Schipanski ME, Hamilton A, Mortensen DA. Weed suppression in cover crop monocultures and mixtures. Weed Sci. 2018;66(1):121-33. Available from: https://doi.org/10.1017/wsc.2017.59

Boiarskii B, Hasegawa H. Comparasion of NDVI and NDRE indices to detect differences in vegetation and chlorophyll content. J Mech Cont Math Sci. 2019;(spe.4):20-9. Available from: https://doi.org/10.26782/ jmcms.spl.4/2019.11.00003

Brust J, Claupein W, Gerhards R. Growth and weed suppression ability of common and new winter crops in Germany. Crop Prot. 2014;63:1-8. Available from: https://doi.org/10.1016/j.cropro.2014.04.022

Cargnin A, Santos LDT, Pinto JJO, Sofiatti V. [Use of selective herbicides in white oat]. Rev Ceres. 2006;53(306):139-43. Portuguese.

Carvalho SJP, Nicolai M, Ferreira RR, Figueira AVO, Christoffoleti PJ. Herbicide selectivity by differential metabolism: considerations for reducing crop damages. Sci. Agric. 2009;66(1):136-42. Available from: https://doi.org/10.1590/S0103-90162009000100020

Cruz DC, Regazzi AJ, Carneiro PCS. [Biometric models applied to genetic improvement]. 4th ed. Viçosa: Universidade Federal de Viçosa; 2012. Portuguese.

Dalazen G, Kruse ND, Machado SLO. [Herbicides with potential use in the control of hairy fleabane and their selectivity in oats and ryegrass]. Rev Cienc Agron. 2015;46(4):792-9. Portuguese.

Didon UME, Kolseth AK, WidmarkD, Persson P. Cover crop residue: effects on germination and early growth of annual weeds. Weed Sci. 2014;62(2):294302. Available from: https://doi.org/10.1614/WS-D-13-00117.1

Diel MI, Lúcio AD, Lambrecht DM, Pinheiro MVM, Sari BG, Olivoto T et al. Canonical correlations in agricultural research: mxethod of interpretation used leads to greater reliability of results. Int J Inn Educ Res. 2020;8(7):17181. Available from: https://doi.org/10.31686/ijier.vol8.iss7.2464

Dieleman JA, Mortensen DA, Buhler DD, Cambardella CA, Moorman TB. Identifying associations among site properties and weed species abundance l: multivariate analysis. Weed Sci. 2000;48(5):567-75. Available from: https:// doi.org/10.1614/0043-1745(2000)048[0567:IAASPA]2.0.CO;2

Freeman KW, Raun WR, Johnson GV, Mullen RW, Stone LM, Solie JB. Late-season prediction of wheat grain yield and grain protein. Comm Soil Sci Plant An. 2003;34(13-14):1837-52. Available from: https://doi. org/10.1081/CSS-120023219

Grossmann K, Niggeweg R, Christiansen N, Looser R, Ehrhardt T. The herbicide saflufenacil $\left(\mathrm{Kixor}^{\mathrm{TM}}\right)$ is a new inhibitor of protoporphyrinogen IX oxidase activity. Weed Sci. 2010;58(1):1-9. Available from: https://doi.org/10.1614/WS-D-09-00004.1
Hair Jr JF, Black WC, Babin BJ, Anderson RE. [Multivariate data analysis]. 6th ed. Porto Alegre: Bookman; 2009. Portuguese.

Hayden ZD, Ngouajio M, Brainard DC. Rye-vetch mixture proportion tradeoffs: cover crop productivity, nitrogen accumulation, and weed suppression. Agronomy J. 2014;106(3):904-14. Available from: https://doi.org/10.2134/agronj2013.0467

Heldwein AB, Buriol GA, Streck NA. [The climate of Santa Maria]. Cienc Amb. 2009;38:43-58. Portuguese.

Henry WB, Shaw DR, Reddy KR, Bruce LM. Remote sensing to detect herbicide drift on crops. Weed Technol. 2004;18(2):358-68. Available from: https://doi.org/10.1614/WT-03-098

Hess FD. Light-dependent herbicides: an overview. Weed Sci. 2000;48(2):160-70. Available from: https://doi.org/10.1614/0043-174 5(2000)048[0160:LDHAO]2.0.CO;2

Monquero PA, Binha DP, Inácio EM, Silva PV, Amaral RL. [Selectivity of herbicides in varieties of sugarcane]. Bragantia. 2011;70(2):286-93. Portuguese. Available from: https://doi.org/10.1590/S0006-87052011000200006

Ollinger SV. Sources of variability in canopy reflectance and the convergent properties of plants. New Phytologist, 2011;189(2):375-94. Available from: https://doi.org/10.1111/j.1469-8137.2010.03536.x

Pittman KB, Barney JN, Flessner ML. Horseweed (Conyzo conodensis) suppression from cover crop mixtures and fall-applied residual herbicides. Weed Technol. 2019;33(2):303-11. Available from: https://doi.org/10.1017/wet.2018.111

Queiroz ARS, Vidal RA, Nava IC, Federizzi LC, Xavier E. Selectivity of iodosulfuron-methyl to oat cultivars. Planta Daninha. 2017;35:1-9. Available from: https://doi.org/10.1590/S0100-83582017350100022

R Development Core Team. R: a language and environment for statistical computing. Vienna: R Foundation for Statistical Computing; 2019.

Santos HG, Jacomine PKT, Anjos LHC, Oliveira VA, Lumbreras JF, Coelho MR et al. [Brazilian system of soil classification]. 3rd ed. Brasília: Empresa Brasileira de Pesquisa Agropecuária; 2013. Portuguese.

Sterling TM, Hall JC. Mechanism of action of natural auxins and the auxinic herbicides. Rev Toxicol. 1997;1(3):111-42.

Taylorson RB, Borthwick HA. Light filtration by foliarcanopies: significance for light-controlled weed seed germination. Weed Sci. 1969;17(1):48-51. Available from: https://doi.org/10.1017/S0043174500030873

Vargas L, Roman ES. [Selectivity and efficacy of herbicides to winter cereals]. Rev Bras Herb. 2005;4(3):1-10. Portuguese. Available from: https://doi.org/10.7824/rbh.v4i3.32

Yamashita OM, Guimarães SC, Cavenaghi AL. [Germination of Conyza canadensis and Conyza bonariensis seeds as a function of light quality]. Planta Daninha. 2011;29(4):737-43. Portuguese. Available from: https://doi.org/10.1590/S0100-83582011000400003

Zadoks JC, Chang TT, Konzak CF. A decimal code for the growth stages of cereals. Weed Res. 1974;14(6):415-21. Available from: https://doi.org/10.1111/j.1365-3180.1974.tb01084.x 